\title{
The Effect of Participatory Budgets on The Performance of School (Studies in Smk Sumbawa)
}

\author{
Siti Nur Aisyah \\ Sutisno \\ Erwin Saraswati \\ Magister Akuntansi, Universitas Brawijaya Malang \\ Buais880@gmail.com
}

\begin{abstract}
This study was aimed to empirically analyze the effect of participatory budgeting on the school's performance with organizational commitment, organizational culture, and leadership styles as the moderating variabels. The populations in this study are educators, educational personnel, committe of 801 people and spread at the vocational high schools in Sumbawa regency comprising 17 private and public schools. The disproportionate stratified simple random sampling was used as sampling technique. There are 278 repondents (educators, educational personnel, committee). The analysis method involved SEM PLS and Smart PLS 2.0 as statistic test tools. The result showed that the participatory budgeting affected the school performances. The organizational commitment and leadership styles were able to moderate the effect of participatory budgeting on performances. The leadership styles focusing on the preference and skill of the subordinates became the main concern and the commitment of the members to the organization supported the performance of the schools.
\end{abstract}

Keywords: Participatory Budgeting, Performance, Leadership Styles, Organizaional Culture, Organizational Commitment

\begin{abstract}
Abstrak: Penelitian ini bertujuan untuk menganalisis secara empiris pengaruh penganggaran partisipatif terhadap kinerja sekolah dengan komitmen organisasi, budaya organisasi dan gaya kepemimpinan sebagai variabel moderasi. Populasi dalam penelitian ini adalah tenaga pendidikan, tenaga kependidikan dan komite sebanyak 801 orang yang tersebar di SMK se Kabupaten Sumbawa dengan jumlah 17 SMK baik Swasta maupun Negeri. Pengambilan sampel dilakukan secara Disproportionate Stratified random sampling, sehingga didapatkan 278 responden (tenaga pendidik, tanaga kependidikan dan komite). Metode analisis dalam penelitian ini menggunakan SEM PLS dengan SmartPLS 2.0 sebagai alat uji statistik. Hasil penelitian ini menunjukkan bahwa penganggaran partisipatif berpengaruh terhadap kinerja sekolah. Komitmen organsiasi dan gaya kepemimpinan memoderasi pengaruh penganggaran partisipatif terhadap kinerja. Budaya organisasi tidak dapat memoderasi pengaruh penganggaran partisipatif terhadap kinerja. Gaya kepemimpinan yang mengarah pada kemauan dan kemampuan bawahan menjadi perhatian khusus serta komitmen anggota yang kuat terhadap organisasi akan memberikan penguatan pada kinerja sekolah.
\end{abstract}

Kata Kunci: penganggaran partisipatif, kinerja, gaya kepemimpinan, budaya organisasi dan komitmen organisasi

Kinerja merupakan suatu kombinasi dari motivasi yang ada pada diri seseorang dengan kemampuan dalam melakukan suatu pekerjaan (Fieldmen, 1986). Kinerja sekolah dalam hal ini tentunya terkait dengan hasil kerja yang dicapai seluruh warga sekolah dalam suatu 
lembaga dengan tanggung jawab yang ada, serta wewenang dalam mencapai suatu tujuan lembaga itu sendiri. Kinerja sekolah menunjukkan adanya deskripsi kerja yang mengacu pada proses dan produk yang diinginkan dengan situasi sekolah yang diselenggarakan (Ikhsan, 2010). Pengukuran kinerja suatu organisasi mempunyai banyak dimensi, hal ini terkait dengan bentuk organisasi yang dijalankan dan tujuan organsiasi (Rasto, 2010). Sekolah sebagai salah satu organsiasi yang mempunyai tugas utama memberikan pelayanan dalam pendidikan yang bermutu kepada masyarakat, penilaian kinerja mengacu pada Standar Nasional Pendidikan yang tertuang dalam PP nomor 32 tahun 2013 sebagai perubahan atas PP nomor 19 tahun 2005.

Sekolah sebagai institusi pendidikan memberikan gambaran kualitas pendidikan yang tidak terlepas dari kualitas pelayanan pendidikan. Menurut Menteri pendidikan (Baswedan,2014) bahwa pendidikan di Indonesia mengalami kondisi gawat darurat yaitu dengan adanya data 75 persen sekolah di Indonesia tidak memenuhi standar layanan pendidikan. Data kemendikbud tahun 2012 sejumlah 40.000 sekolah masih belum mampu memberikan standar pelayanan pendidikan yang baik sesuai dengan amanat undang-undang terutama pada standar isi, proses, fasilitas dan pengelolaan. Salah satu upaya pemerintah yaitu dengan memberikan standar pelayanan pendidikan yang sesuai dengan standar nasional pendidikan seperti yang tertera pada PP nomor 32 tahun 2013.

Selanjutnya, akreditasi sekolah sebagai acuan dalam menilai kinerja sekolah dengan melihat fungsi dari akreditasi sekolah yaitu menemukan tingkat kelayakan suatu sekolah dalam penyelenggaraan pendidikan dan memperoleh gambaran tentang kinerja sekolah. Sekolah merupakan layanan publik yang menyentuh langsung pada masyarakat, sehingga diperlukan adanya standar pelayanan yang seharusnya disediakan (Rasto, 2010). Standar pelayanan telah di paparkan dalam PP nomor 32 tahun 2013 yang terdiri dari 8 standar pendidikan nasional dan telah dijadikan sebagai indikator dalam menentukan akreditasi sekolah sesuai dengan dasar hukum UU no 20 tahun 2003 pasal 60.

Penilaian kinerja sekolah sebenarnya sudah terpaparkan dalam hasil penilaian dari BAS-NAS (Badan Akreditasi Sekolah), dalam penilaian akreditasi sekolah terdapat komponen 8 Standar Pendidikan Nasional. Berdasarkan hasil penilaian akreditasi sejumlah 6.191 SMK di Indonesia sudah melalui proses penilaian akreditasi. Hasil akreditasi BAN-SM terhadap jumlah sekolah yang sudah melalui proses akreditasi, mempunyai peringkat yang berbeda-beda diantaranya peringkat A sebanyak 3.042 sekolah, peringkat B sebanyak 2.488 sekolah, peringkat C sebanyak 590 sekolah dan tidak terakreditasi sebanyak 71 (BAN-SM, 
2015). Perbedaan hasil dari akreditasi ini menunjukkan adanya variasi dalam pemenuhan standar layanan pendidikan yang sesuai dengan indikator yang ditetapkan oleh BAN-SM dan sesuai dengan PP 32 tahun 2013.

Anggaran dalam sektor publik harus mempunyai pengawasan yang tepat dari tahap perencanaan, pelaksanan hingga pelaporan anggaran, karena hal ini terkait dengan sumber pembiyaan yang berasal dari masyarakat dan sifatnya adalah amanah masyarakat (Bahar, 2008). APBS (Anggaran Pendapatan dan Belanja Sekolah) merupakan suatu anggaran yang disusun oleh kepala sekolah selaku pimpinan sekolah dan guru, serta partisipasi dari orang tua murid dan masyarakat sekitar yang peduli terhadap pendidikan yang ada (Abudinnata, 2003). APBS ini merupakan patokan pelaksanaan program selama satu tahun pelajaran yang terdiri dari perencanaan, pelaksanaan dan pertanggung jawaban.

Peran serta dalam penyusunan anggaran diharapkan mampu memberikan kinerja yang baik, karena akan menjadi keterlibatan tersendiri bagi peran serta atau dianggap adanya penghargaan atas peran masing-masing partisipan yang peduli pada pendidikan. Hubungan antara pengpenganggaran partisipatif dengan kinerja dijelaskan melalui Behavioral Theory, yang menjelaskan bahwa dengan memberikan kesempatan pada manajer berbagai tingkat dalam penyusunan anggaran akan lebih memberikan motivasi dan tanggung jawab terhadap pekerjaan yang diembannya sehingga diharapkan adanya kinerja yang baik. Pendekatan penganggaran yang dianggap paling efektif adalah anggaran yang melibatkan partisipasi dari manajer seluruh tingkatan (Garrison dan Noreen, 2007). Keterlibatan akan memberikan pengawasan untuk mencapai tujuan keberhasilan dari perencanaan ataupun program-program yang ada mampu tercapai. Menurut Muhroji (2012) bahwa partisipasi atau keterlibatan Stakeholder dalam merancang APBS akan mempengaruhi kinerja yang dilakukan dalam institusi pendidikan. Hanafi (2015) memperlihatkan minimnya keterlibatan komite dalam penyusunan APBS, keterlibatan komite hanya sebatas penandatanganan APBS yang telah disusun.

Partisipasi penyusunan anggaran dapat meningkatkan kinerja manajerial (Brownell dan Mc Innes, 1986; Sumarno, 2005; Nor, 2007; Indarto, 2011). Sebaliknya, partisipasi penyusunan anggaran tidak dapat meningkatkan kinerja manajerial (Nazaruddin, 2012; Sutrisna, 2011; Biduri, 2013). Penyusunan anggaran mampu meningkatkan kinerja jika dipengaruhi oleh faktor lain seperti komitmen organisasi, jika anggota organisasi mempunyai komitmen yang kuat terhadap organisasi akan memberikan peningkatan terhadap kinerja 
organsisasi. Budaya organisasi yang mendukung adanya kinerja yang baik serta gaya kepemimpinan dari organisasi yang lebih mengarahkan pada kinerja bawahan.

Kinerja sekolah yang baik dapat digambarkan pada pemberian standar layanan pendidikan yang memadai yaitu melalui penilaian akreditasi yang didapatkan oleh masingmasing sekolah. Penelitian ini dilakukan di Sumbawa khususnya SMK yang berada di Sumbawa, dengan alasan bahwa sampai pada tahun 2016 (berdasarkan data Dapodik 2016) jumlah SMK di Kabuapaten Sumbawa yang memiliki akreditasi A sebanyak satu sekolah dari 17 sekolah yang ada. Hal ini mengindikasikan bahwa pemberian standar pelayanan pendidikan belum mencapai tahap maksimal, sehingga diperlukan adanya penelitian mengenai faktor yang dapat mempengerahui kinerja sekolah ataupun dapat meningkatkan kinerja sekolah sehingga standar layanan pendidikan dapat dicapai dengan hasil maksimal melalui angka akreditasi yang didapatkan.

\section{Teori Behavior}

Teori Behavior atau biasa disebut dengan teori keprilakuan dapat dipakai untuk menjelasakan hubungan antara penganggaran partisipatif dengan kinerja. Riset tentang akuntansi keperilakuan sebenarnya sudah ada sejak tahun 1952 yang dilakukan oleh Argyris, dalam perkembangannya akuntansi keperilakuan dikenal dengan istilah Bahavioral accounting research (BAR) yang diperkenalkan oleh Becker, dengan konsepnya menguji hubungan antara suatu informasi dan proses akuntansi dengan perilaku manusia. Ardiansyah (2009) menyatakan bahwa akuntansi keperilakuan memperhatikan hubungan antara perilaku manusia dengan akuntansi, dengan orientasi profesional serta pendekatan praktis. Becker (1967) menjelasakan bahwa penelitian akuntansi keperilakuan memberikan penekanan pada aplikasi teori dan metodologi dari ilmu keperilakuan guna mempelajari hubungan antara informasi dan proses akuntansi dengan perilaku individu (manusia) termasuk juga perilaku organisasi.

\section{Teori Kontijensi}

Teori kontijensi mempunyai asumsi bahwa jika suatu organisasi ingin mencapai kinerja yang baik, harus menyesuaikan sistem terhadap kondisi ketidakpastian seperti lingkungan, ukuran organisasi, dan strategi bisnis yang dipakai (Gerdin dan Grave, 2004). Teori kontijensi mampu untuk menganalisis desain dan sistem akuntansi untuk memberikan informasi yang dapat digunakan perusahaan untuk berbagai macam tujuan (Otley, 1980). Pendekatan kontijensi mengevaluasi faktor-faktor kondisional. Penelitian terdahulu (Sutrisna, 
2011; Biduri, 2013; Sarjito dan Muhtaher, 2007) mengenai penyusunan anggaran terhadap kinerja melihat adanya variabel lain, seperti gaya kepemimpinan, desentralisasi dan budaya organisasi yang menyebabkan kinerja menjadi lebih efektif. Penelitian ini menggunakan pendekatan teori kontijensi ketika menghubungkan pengaruh penganggaran partisipatif terhadap kinerja, diantaranya dengan menggunakan faktor kontijensi komitmen organisasi, budaya organisasi dan gaya kepimpinan.

\section{Kinerja Sekolah}

Kinerja menurut Mangkunegara (2007) merupakan suatu hasil baik secara kualitas maupun kuantitas yang dicapai oleh seseorang pegawai yang dilakukan sesuai dengan tugas yang diberikan kepadanya. Kinerja menurut Nawawi (2004) merupakan suatu hasil dari pelaksanaan dari pekerjaan baik bersifat fisik maupun non fisik. Konsep kinerja organisasi yang dikemukakan oleh Tangkilisan (2007) menunjukkan suatu keadaan yang berkaitan dengn keberhasilan dari organisasi dalam menjalankan misinya. Berdasarkan konsep organisasi, sekolah dapat dikatakan sebagai suatu organisasi yang di dalamnya terdapat visi dan misi yang jelas.

Pengukuran kinerja dirasakan sangat penting karena dengan pengukuran kinerja organisasi akan mampu mendorong untuk mencapai tujuan dari organisasi dan akan memberikan umpan balik untuk melakukan perbaikan secara berkelanjutan, hal ini sesuai dengan yang dikemukakan oleh Bastian (2001). Pengukuran kinerja suatu organisasi mempunyai banyak dimensi, seperti yang diungkapkan Sekolah sebagai suatu organisasi dengan tugas utama adalah pelayanan dibidang pendidikan kepada masyarakat, maka diperlukan pengukuran kinerja yang tepat. Terkait dengan sekolah adalah salah satu organisasi pemerintahan, maka pemerintah telah memberikan standar mutu pendidikan nasional dengan melihat delapan standar pendidikan nasional yang tertera dalam PP nomor 32 tahun 2013 sebagai pengganti PP nomor 19 tahun 2005. Delapan standar tersebut diantaranya: standar kompetensi lulusan, standar isi, standar proses, standar pendidik dan tenaga kependidikan, standar sarana dan prasarana, standar pengelolaan, standar pembiayaan, standar penilaian pendidikan.

\section{Penganggaran partisipatif dalam APBS}

Mardiasmo (2009) menyatakan bahwa anggaran merupakan pernyataan mengenai suatu estimasi kinerja yang sebenarnya akan dicapai dalam suatu periode waktu tertentu dan mempunyai ukuran finansial. Menurut Gomes (1995) anggaran dimaksudkan sebagai suatu 
dokumen yang berusaha untuk mendamaikan prioritas-prioritas program dengan sumber pendapatan yang diproyeksikan. Faisal (2009) menyatakan bahwa APBS merupakan keterpaduan penerimaan dan pengunaan dana serta pengelolaan selama satu tahun pelajaran.

Penyusunanan APBS diperlukan persetujuan beberapa pihak diantaranya manajemen dalam sekolah dan juga pihak komite yang merupakan bagian dari organisasi sekolah, sehingga dalam pembentukan APBS diperlukan partisipasi pihak-pihak tersebut. Partisipasi dalam kamus besar bahasa indonesia diartikan sebagai keikutsertaan atau peran serta dalam suatu kegiatan. Menurut Mulyadi (2001) partisipasi merupakan suatu proses dalam pengambilan keputusan yang dilakukan oleh dua orang atau lebih dan keputusan tersebut mempunyai dampak pada jangka panjang.

Partisipasi dalam pendidikan telah dituangkan dalam UU sistem Pendidikan Nasional No. 20 Tahun 2003. UU tersebut telah dijelaskan bahwa pendanaan pendidikan merupakan tanggung jawab pemerintah pusat dan juga daerah, selain itu juga menjadi tanggung jawab bagi masyarakat setempat untuk mampu memberikan konstribusi dalam memberikan mutu layanan pendidikan.

\section{Gaya Kepemimpinan}

Robbin (2003) menjelaskan bahwa kepemimpinan sebagai kemampuan dalam memberikan pengaruh pada kelompok untuk diarahkan pada pencapaian tujuan. Pendapat ini juga didukung oleh Rivai (2005) bahwa kepemimpinan merupakan proses dalam mempengaruhi suatu organisasi dengan memberikan motivasi perilaku pada anggota yang mengikutinya dalam mencapai suatu tujuan organisasi. Kartono (2006) memberikan pandangan bahwa kepemimpinan merupakan suatu kekuatan aspirasional dengan semangat dan kekuatan moral yang kreatif dan diharapkan mampu mengubah sikap. Dari beberapa pendapat ini maka dapat disimpulkan bahwa kepemimpinan merupakan suatu proses mempengaruhi anggota organisasi untuk mencapai tujuan organisasi itu sendiri

Teori kepemimpinan situasional adalah teori yang memusatkan perhatian dari para pengikut (bawahan), teori ini lebih menekankan pada upaya terbaik untuk mempengaruhi perilaku orang-orang. Gaya kepemimpinan yang dipakai mampu diterapkan oleh seseorang terhadap kelompok orang yang mempunyai level kematangan, gaya kepemimpinan ini merupakan kombinasi perilaku tugas (direktif) dan perilaku hubungan (suportif) yang sesuai (Harsey dan Blanchard, 1982). Teori kepemimpinan Harsey dan Blancahard, dikelompokkan dalam gaya berorientasi tugas (task oriented) dan Orientasi Hubungan (relationship 
oriented), secara lebih terinci diindikasikan dalam empat gaya kepemimpinan yaitu: Telling, Selling, Participating dan Delegetaing. Perkembangan terhadap kritikan teori ini, dikembangkan lebih lanjut dengan melakukan perbaikan seperti "perilaku tugas" disebut perilaku direktif dan "perilaku hubungan" disebut perilaku suportif, selanjutnya gaya kepemimpinan disebut dengan: Directing, Coaching, Supporting dan Delegating (Gibson et. a.1, 1995).

\section{Komitmen Organisasi}

Ikhsan dan Ishak (2005) berpendapat bahwa komitmen organisasi merupakan suatu bentuk ukuran sejauh mana seseorang untuk memihak kepada organisasi yang diikutinya serta berminat dalam mempertahankan keanggotaannya. Mowday, et al (1982) komitmen organisasi ditunjukkan dengan loyalitas pekerja secara terus menerus guna keberhasilan dan kesejahteraan anggotanya. Komitmen ini menunjukkan adanya dorongan yang kuat dalam berusaha sebaik mungkin dalam keikutsertaan untuk mencapai tujuan organisasi, seperti yang diungkapkan oleh Angel dan Perry (1981) bahwa komitmen organisasi yang kuat akan mendorong individu untuk berusaha keras mencapai tujuan

Komitmen merupakan suatu keadaan dari seorang individu untuk lebih meningkatkan diri pada organisasi yang diikutinya dengan menunjukkan adanya kemauan atau dorongan untuk membantu organisasi mencapai tujuan dengan menunjukkan kinerja yang baik. Menurut Meyer dan Allen (1997) terdapat tiga komponen dalam komitmen organisasi, yaitu: komitmen affective, komitmen constituance, dan komitmen normative.

\section{Budaya Organisasi}

Abdullah dan Arisanti (2010) menjelaskan bahwa budaya organisasi merupakan suatu sistem organsiasi yang dianut, kemudian memberikan pengaruh dalam tata cara mereka berorganisasi. Nurjanah (2008) memberikan pendapat bahwa budaya organisasi merupakan suatu bentuk ikatan yang memberikan nilai-nilai simbolis dan ide-ide yang bersifat pengikat para anggotanya dalam suatu organisasi. Kurniawan (2011) budaya organisasi merupakan sistem nilai-nilai yang diyakini oleh semua organisasi yang dipelajari, diterapkan serta dikembangkan secara berkesinambungan.

Robbins (2003) dengan mengembangkan model O’Reilly (2002) menjelaskan tujuh karakteristik budaya organsiasi yang mempunyai pengaruh terhadap efektivitas kinerja yang dapat dicapai oleh organsasi yaitu: 1). Inovasi dan keberanian dalam mengambil resiko (Innovation and risk taking), 2). Perhatian terhadap detail (attention to detail), 3). 
Berorientasi pada hasil (outcome orientation), 4). Berorientasi pada manusia atau karyawan (people orientation), 5) Berorientasi pada tim (team orientation), 6) Keagresifan (aggressiveness), 7) Stabilitas atau kemantapan (stability).

Rerangka konseptual dalam penelitian ini yaitu menghubungkan anatara keterlibatan anggota organisasi dalam partisipasi suatu anggaran dengan kinerja, hal ini di jelaskan dengan teori Behavior. Selanjutnya, dengan berdasarkan teori kontijensi yang menjelaskan bahwa terdaat penyesuaian sistem terhadap kondisi ketidapastian seperti lingkungan, ukuran organisasi dan startegi bisnis yang dipakai. Maka, penelitian ini mencoba mmeasukkan variabel komitmen organsiasi, budaya organsiasi dan gaya kepemimpinan sebagai vaariabel moderasi yang berfungsi sebagai penguat adanya kinerja sekolah dengan berdasarkan teori kontijensi. Dengan beberapa penelitian terdahulu, maka hipotesis yang diajukan dalam penelitian yaitu : 1) Terdapat pengaruh positf penganggaran partisipatif terhadap kinerja, 2) Komitmen organisasi memoderasi pengaruh penganggaran partisipatif terhadap kinerja, 3) Budaya organisasi memoderasi pengaruh penganggaran partisipatif terhadap kinerja, 4) Gaya kepemimpinan memoderasi pengaruh penganggaran partisipatif terhadap kinerja.

\section{METODE}

Penelitian ini berbentuk penelitian kuantitatif. Jenis penelitian ini adalah penelitian Explanatory Research (penelitian penjelasan) yaitu penelitian yang berusaha memberikan penjelasan hubungan kausal antar variabel-variabel dalam penelitian melalui pengujian hipotesis yang telah dirumuskan (Singarimbun dan Effendi, 2006). Metode survei dilakukan sebagai pendekatan dalam pengumpulan data dari objek penelitian dengan memberikan beberapa pertanyaan.

Populasi dalam penelitian ini adalah seluruh tenaga pendidik, kependidikan dan ketua komite SMK se Kabupaten Sumbawa yaitu sebanyak 801 orang. Teknik pengambilan sampel dengan menggunakan Disproportionate Stratified Random Sampling. Penentuan jumlah sampel menggunakan rumus Slovin, dengan nilai $\alpha$ 5\% didapatkan jumlah sampel sebanyak 278 orang, pembagian sampel pada kelompok tenaga pendidik, tenaga kependidikan dan komite dengan penetapan 33\%, kecuali pada kelompok komite sampel yang diambil secara keseluruhan mengingat bahwa jumlah populasi adalah sebanyak 17 dan mengikuti prosedur penarikan sampling secara disproportional.

Teknik pengumpulan data yang dilakukan dengan melalui tiga tahap yaitu : 1) pilot test, tahap ini dilakukan untuk menguji instrument yang akan dipakai dalam penelitian. 2) 
Persiapan pengumpulan data dengan cara penyiapan surat ijin penelitian. 3) Pengumpuan data dengan cara pembagian kuesioner secara langsung.

Definisi operasional dalam penelitian ini disesuaikan dengan jumlah konstruk yang diajukan dalam model penelitian, penelitian ini menggunakan 5 konstruk yang bersifat unidimensional. Konstruk unidimensional merupakan konstruk yang dibentuk dari indikatorindikator, serta konstruk yang digunakan bersifat unidimensional reflektif (Hartono, 2011). Penganggaran partisipatif merupakan keterlibatan anggota organisasi dalam menentukan dan menyusun anggaran. Instrument yang digunakan untuk mengukur konstruk dalam penelitian ini diadopsi dari Brownel (1982) dan telah dipakai oleh Sardjito dan Muhtaher (2007), Musyarofah (2003), serta di modifikasi oleh peneliti, disesuaikan dengan objek penelitian. Penganggaran partisipatif diukur dengan dua indikator, yaitu: (1) Pengaruh Anggota dalam keputusan penyusunan Anggaran, dan (2) Keterlibatan dalam penyusunan anggaran.

Komitmen organisasi merupakan adanya keyakinan kuat terhadap tiap individu untuk memberikan dukungan terhadap tujuan dan nilai organisasinya. Konstruk komitmen yang digunakan dalam penelitian ini menggunakan instrument yang dikembangkan oleh Monday et al. (1979) dan telah digunakan oleh Sardjito dan Muhtaher (2007) serta dimodifikasi oleh peneliti dengan menyesuaikan objek penelitian. Konstruk ini diukur dengan tiga indikator, yaitu: (1) Komitmen yang berbentuk Affective, (2) Komitmen yang berbentuk Constituance, dan (3) Komitmen yang berbentuk Normative.

Gaya kepemimpinan merupakan persepsi responden mengenai perilaku dan strategi yang ditampilkan oleh pemimpin ketika mencoba memberikan pengaruh kepada bawahannya. Gaya kepemimpinan yang dikemukakan oleh Harsey dan Blanchard (1982) diukur dengan menggunakan instrumen yang dikembangkan oleh Luthas (2006) dan telah dipakai oleh Kurniawati (2013). Gaya Kepemimpinan diukur dengan 4 indikator, yaitu: (1) Gaya Kepemimpinan Directing, (2) Gaya Kepemimpinan Coaching, (3) Gaya kepemimpinan Suporting, dan (4) Gaya kepemimpinan Delegating.

Budaya organisasi merupakan suatu nilai yang dimiliki atau diyakini oleh anggota dalam suatu organisasi dan diwujudkan dalam bentuik norma atau perilaku dari para individu dalam organisasi tersebut (Hostede et al., 1990). Pengukuran konstruk budaya organisasi dalam penelitian ini mengunakan instrument yang dikembangkan oleh Robbins (2003) dan dikutip oleh Kurniawati (2013). Budaya organsiasi di ukur dengan tujuh indikator, yaitu: (1) Inovasi, (2) Perhatian yang detail, (3) Orientasi Hasil, (4) Orientasi pada individu, (5) Orientasi tim, (6) Keagresifan, dan (7) Stabilitas. 
Kinerja sekolah merupakan kinerja yang ditunjukkan oleh anggota organisasi dalam lingkup sekolah, tenaga pendidikan khususnya dan persepsi tenaga kependidikan dan komite. Kinerja sekolah diukur dengan menggacu pada PP nomor 19 tahun 2005 dengan diperbaharui oleh PP nomor 32 tahun 2013. Kinerja sekolah mencakup 8 dimensi yaitu: (1) kurikulum (isi), (2) Proses, (3) Kompetensi Lulusan, (4) Penilaian, (5) Pendidik dan Tenaga, (6) Sarana dan Prasarana, (7) Pengelolaan, dan (8) Pembiayaan. Variabel kinerja sekolah diukur dengan menggunakan instrument yang dikembangkan oleh Rasto (2010) dan dimodifikasi oleh peneliti.

\section{Metode Analisis Data}

Analisis data dalam penelitian ini menggunakan PLS (Partial Least Square). Analisis yang dipakai dalam penelitian ini adalah Structural Equation Model (SEM) dengan pendekatan Partial Least Square (PLS), alasan SEM digunakan adalah: (1) SEM mampu menguji model penelitian yang kompleks secara simultan, dan (2) SEM mampu menganalisis variabel yang tidak dapat diukur langsung (unobserved variabels) dan memperhitungkan kesalahan pengukurnya (Sholihin, 2013). Alat analisis Part Least Square dengan mempertimbangkan bahwa PLS mampu menghasilkan informasi yang efisien dan mudah diinterpretasikan tertutama pada model yang kompleks dan hipotesis model, data dengan set kecil mampu digunakan, mampu digunakan pada indikator yang bersifat reflektif dan formatif terhadap variabel laten, tidak mensyaratkan data berdistribusi normal, mampu mengelola masalah multikolinearitas antara variabel independen, hasil tetap kokoh (robust) walaupun terdapat data yang tidak normal dan hilang (Hartono dan Abdillah, 2015).

Sebelum melakukan penelitian lapangan, terlebih dahulu dilakukan uji pilot dengan tujuan untuk mengetahui validitas dan reliabilitas dari konstruk, dengan menggunakan aplikasi SmartPLS 2.0, Hasil uji pilot menunjukkan bahwa variabel penganggran partisipatif, kinerja sekolah, komitmen organsiasi, budaya organsiasi dan gaya kepemimpinan dinyatakan valid secara diskriminan maupun konvergen dengan nilai outer loading rata-rata diatas 0,7 dan AVE (Average variance extracted) lebih dari 0,5. Seluruh variabel juga mempunyai nilai Cronbach's Alpha rata-rata 0,8 sehingga dapat dikatakan reliabel. 


\section{HASIL dan PEMBAHASAN}

HASIL

\section{Response Rate dan Karakteristik Responden}

Penelitian ini merupakan penelitian jenis survei yang menyebarkan kuesioner kepada sampel yang telah dipilih. Sampel yang didapat dari perhitungan sebanyak 278 orang. Peneliti menyampaikan kuesioner dengan mendatangi secara langsung kepada responden dengan pengiriman kuesioner dilakukan pada bulan September 2016. Hasil penyebaran kuesioner 276 sebanyak $241(87 \%)$.

Karakter responden dalam penelitian dapat dijabarkan sebagai berikut: karakteristik responden lebih banyak didominasi oleh jenis kelamin perempuan yaitu sebanyak $51 \%$ dan sisanya $49 \%$ adalah jenis kelamin laki-laki. Faktor usia sebanyak $85 \%$ di isi oleh responden yang berusia lebih dari 30 tahun sisanya 15\% kurang dari 30 tahun, sehingga diindikasikan bahwa dengan kematangan usia responden mampu memberikan pemahaman yang baik dalam penyusunanan anggaran dan lebih banyak memahami tentang tugas kerja dalam organisasi.

Tingkat pendidikan banyak diisi oleh lulusan S1 dengan persentase 73\% selanjutnya D3 sebanyak 12\% diikuti lulusan SMA 7\%, jejang pendidikan yang beragam menunjukan adanya kesesuaian antara kompetensi dari anggota organisasi dalam melaksanakan kinerja dalam organisasi. Responden yang terbagi dalam 3 kelompok, didapatkan persentase sebanyak $73 \%$ untuk tenaga pendidik, 20\% tenaga kependidikan dan $7 \%$ komite. Hal ini sejalan dengan karakteristik organisasi yaitu lebih pada besarnya jumlah tenaga pendidik yang sekaligus sebagai bagian dari organisasi yang lebih banyak menjalankan program kerja organisasi, selanjutnya adalah tenaga kependidikan yang mendukung atas terlaksananya manajemen sekolah, komite sebagai salah satu stakeholder yang memberikan pengaruh pada jalannya manajemen sekolah dalam hal pemberian keputusan terkait dana komite dan pengawasan.

\section{Pengujian Model Pengukuran (Outer Model)}

Model pengukuran dalam penelitian ini adalah indikator reflektif dan dapat di evaluasi dengan validitas konvergen dan diskriminan dari konstruk serta reliabilitas konstruk. Parameter yang digunakan dalam uji validitas konvergen adalah skor outer loading > 0,70, communality> 0,5 dan Average Variance Extraced (AVE) > 0,5. Sementara untuk pengukuran reliabilitas diukur dengan melihat nilai croncbac's alpha>0,6. Instrumen dalam penelitian ini memenuhi kriteria validitas konvergen dan diskriminan. Hasil pengujian validitas tersaji dalam tabel 1 berikut : 
Tabel 1 Pengujian Outer Model

\begin{tabular}{|c|c|c|c|c|c|c|}
\hline Variabel & Indikator & $\begin{array}{l}\text { Loading } \\
\text { Factor }\end{array}$ & Communality & AVE & Akar AVE & $\begin{array}{c}\text { Cronbach } \\
\text { Alpha }\end{array}$ \\
\hline \multirow{2}{*}{$\begin{array}{c}\text { Penganggaran } \\
\text { Partisipatif (X1) }\end{array}$} & 1 & 0,866460 & \multirow{2}{*}{0,926602} & \multirow[b]{2}{*}{0,926022} & \multirow[b]{2}{*}{0,962300} & \multirow[b]{2}{*}{0,92321} \\
\hline & 2 & 0,707281 & & & & \\
\hline \multirow{3}{*}{$\begin{array}{c}\text { Komitmen } \\
\text { Organisasi (X2) }\end{array}$} & 1 & 0,966721 & \multirow{3}{*}{0,936877} & \multirow{3}{*}{0,739497} & \multirow{3}{*}{0,859940} & \multirow{3}{*}{0,84171} \\
\hline & 2 & 0,947715 & & & & \\
\hline & 3 & 0,963296 & & & & \\
\hline \multirow{7}{*}{$\begin{array}{c}\text { Budaya } \\
\text { Organisasi (X3) }\end{array}$} & 1 & 0,885499 & \multirow{7}{*}{0,692071} & \multirow{7}{*}{0,936877} & \multirow{7}{*}{0,967920} & \multirow{7}{*}{0,89604} \\
\hline & 2 & 0,889236 & & & & \\
\hline & 3 & 0,857065 & & & & \\
\hline & 4 & 0,802888 & & & & \\
\hline & 5 & 0,940062 & & & & \\
\hline & 6 & 0,946109 & & & & \\
\hline & 7 & 0,802888 & & & & \\
\hline \multirow{4}{*}{$\begin{array}{c}\text { Gaya } \\
\text { Kepemimpinan } \\
(\mathrm{X} 4)\end{array}$} & 1 & 0,700748 & \multirow{4}{*}{0,739497} & \multirow{4}{*}{0,690271} & \multirow{4}{*}{0,830825} & \multirow{4}{*}{0,78123} \\
\hline & 2 & 0,790334 & & & & \\
\hline & 3 & 0,774705 & & & & \\
\hline & 4 & 0,914162 & & & & \\
\hline \multirow{8}{*}{$\begin{array}{c}\text { Kinerja Sekolah } \\
\text { (Y) }\end{array}$} & 1 & 0,874890 & \multirow{8}{*}{0,701402} & \multirow{8}{*}{0,701402} & \multirow{8}{*}{0,837497} & \multirow{8}{*}{0,71625} \\
\hline & 2 & 0,855785 & & & & \\
\hline & 3 & 0,878045 & & & & \\
\hline & 4 & 0,876870 & & & & \\
\hline & 5 & 0,805732 & & & & \\
\hline & 6 & 0,804677 & & & & \\
\hline & 7 & 0,876211 & & & & \\
\hline & 8 & 0,806884 & & & & \\
\hline
\end{tabular}

Sumber: data diolah (2016)

\section{Pengujian Model Struktural (Inner Model)}

Pengujian model struktural dalam analsis PLS disebut dengan uji goodness-fit model berupa nilai $\mathrm{Q}^{2}$ (predictive relevance). Nilai $\mathrm{R}^{2}$ yang didapat dalam penelitian ini sebesar 0,8261 , sehingga didapatkan nilai $\mathrm{Q}^{2} 0,826$, hal ini menunjukkan bahwa model dibangun dengan baik. Varian perubahan kinerja sekolah dalam penelitian ini dipengaruhi sebsar $82,6 \%$ dari variabel independen yang diajukan sebesar 82,6\% sementara 17,4\% dipengaruhi oleh variabel lain diluar penelitian ini.

\section{Pengujian Hipotesis}

Pengujian hipotesis menggunakan persamaan struktural, kemudian dilakukan pembandingan nilai t hitung dengan t tabel. Hipotesis dalam penelitian ini menunjukkan hipotesis dengan satu arah (one tail) sehingga dengan nilai a 5\% maka nilai t tabel yang daidapatkan adalah 1,64. Perbandingan antara nilai t-tabel dengan t-hitung akan menentukan hipotesis diterima atau ditolak, jika nilai t-hitung > t-tabel maka hipotesis diterima, begitu pula sebaliknya jika nilai t-hitung $<$ t-tabel maka hipotesis ditolak. Berdasarkan hasil olah 
data dengan menggunakan SmartPLS 2.0 didapatkan hasil yang disajikan dalam table 2 berikut:

Tabel 2. Uji Hipotesis

\begin{tabular}{|c|c|c|c|c|c|c|c|}
\hline Hipotesis & $\begin{array}{c}\text { Pengaruh } \\
\text { Antar Variabel }\end{array}$ & $\begin{array}{c}\text { Original } \\
\text { Sample } \\
\text { (O) }\end{array}$ & $\begin{array}{c}\text { Sample } \\
\text { Mean } \\
\text { (M) }\end{array}$ & $\begin{array}{l}\text { Standard } \\
\text { Deviation } \\
\text { (STDEV) }\end{array}$ & $\begin{array}{c}\text { Standard } \\
\text { Error } \\
\text { (STERR) }\end{array}$ & $\begin{array}{c}\text { T Statistics } \\
(\mid \text { O/STERR } \mid)\end{array}$ & Kesimpulan \\
\hline H1 & AP $\rightarrow \mathrm{KS}$ & 0,112168 & 0,109164 & 0,043182 & 0,043182 & 2,597555 & Diterima \\
\hline $\mathrm{H} 2$ & $\mathrm{KO} * \mathrm{AP}->\mathrm{KS}$ & 0,108225 & 0,106337 & 0,039633 & 0,039633 & 2,730690 & Diterima \\
\hline $\mathrm{H} 3$ & $\mathrm{BO} * \mathrm{AP} \rightarrow \mathrm{KS}$ & 0,193543 & 0,190520 & 0,071714 & 0,201714 & 0,959491 & Ditolak \\
\hline $\mathrm{H} 4$ & $\mathrm{GK} * \mathrm{AP}->\mathrm{KS}$ & 0,239657 & 0,221635 & 0,128034 & 0,128034 & 1,871813 & Diterima \\
\hline
\end{tabular}

Sumber : data diolah, 2016

Model struktural yang didapatkan dalam penelitian ini adalah sebagai berikut:

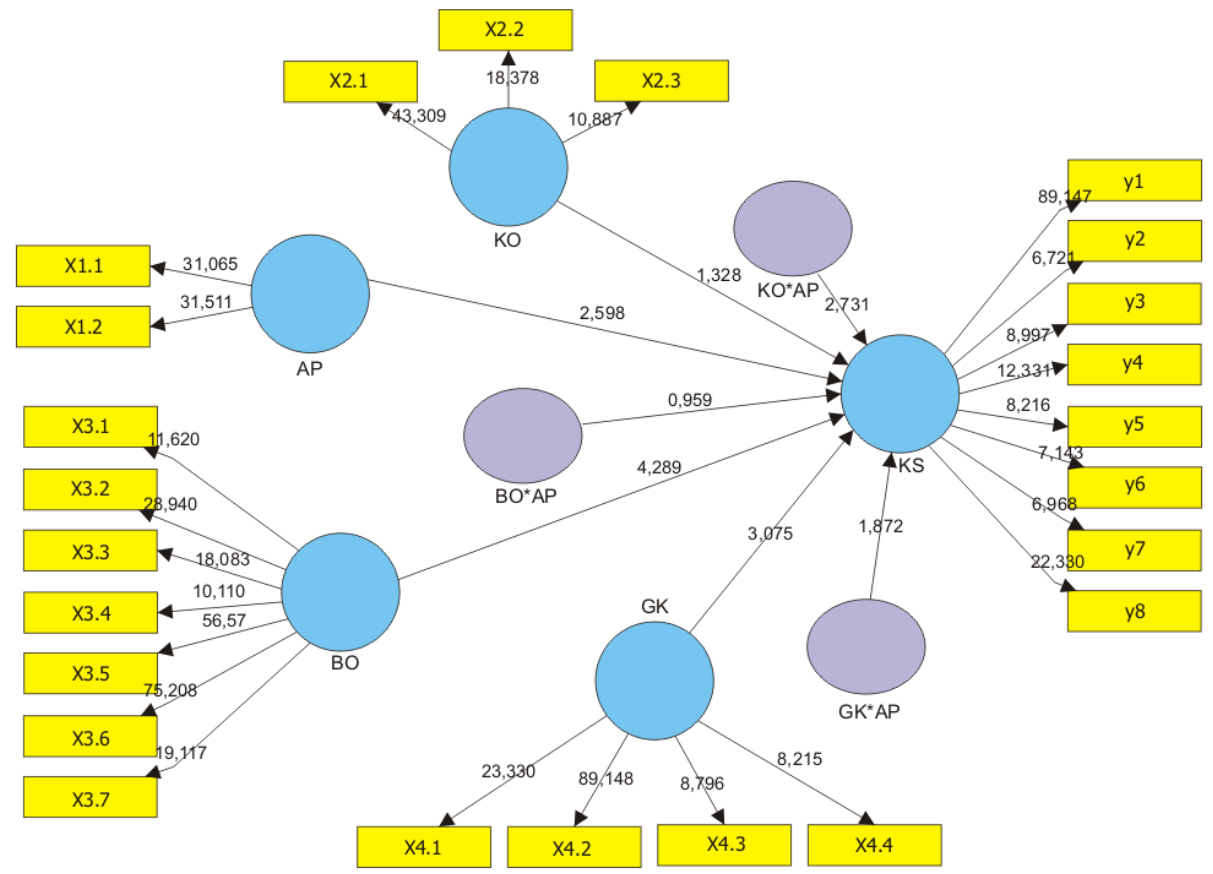

Gambar 1 Model Struktural Penelitian

Pengujian hipotesis pertama (H1) yang menunjukkan adanya koefisien jalur pengaruh secara langsung yaitu pengaruh penganggaran partisipatif terhadap kinerja sekolah. Hasil pengujian didapatkan nilai nilai estimate koefisien sebesar 0,112 . Tanda positif memberikan arti bahwa hubungan antara penganggaran partisipatif dengan kinerja sekolah adalah searah. Selanjutnya dilihat dari nilai T-statistik yaitu sebesar 2,596 dan dibandingkan dengan nilai Ttabel yaitu 1,64, maka nilai $\mathrm{T}$ - statistik > $\mathrm{T}$ - tabel hal ini memberikan pengertian bahwa hipotesis diterima. 
Hipotesis 2 menyatakan bahwa komitmen organisasi mampu memoderasi hubungan antara penganggaran partisipatif terhadap kinerja sekolah. Nilai Total Effect (KO * AP -> KS) yang didapat adalah 2,731. Nilai T- statistik yang didapat lebih dari T-tabel yang ditentukan yaitu 2,73 >1,64, yang berarti hipotesis dua diterima. Bahwa komitmen organisasi mampu memoderasi secara positif pengaruh antara anggaran partisipasi terhadap kinerja sekolah sehingga dapat dijelaskan bahwa semakin tinggi komitmen organisasi maka semakin memberikan penguatan pengaruh antara penganggaran partisipatif terhadap kinerja.

Hipotesis 3 menyatakan bahwa budaya organisasi mampu memoderasi hubungan antara penganggaran partisipatif terhadap kinerja sekolah. Nilai Total Effect (BO * AP -> KS) yang didapat adalah adalah 0,959 . Nilai $\mathrm{T}$ statistik yang didapat lebih dari $\mathrm{T}$ tabel yang ditentukan yaitu $0,959<1,64$, yang berarti hipotesis ketiga ditolak. Bahwa budaya organisasi tidak mampu memoderasi pengaruh antara anggaran partisipasi terhadap kinerja sekolah sehingga dapat dijelaskan bahwa dengan adanya budaya organisasi sebagai variabel moderasi maka memperlemah pengaruh penganggaran partisipatif terhadap kinerja sekolah.

Hipotesis 4 menyatakan bahwa gaya kepemimpinan mampu memoderasi hubungan antara penganggaran partisipatif terhadap kinerja sekolah. Nilai Total Effect (GK*AP -> KS) yang didapat adalah 1,87 . Nilai $\mathrm{T}$ statistik yang didapat lebih dari $\mathrm{T}$ tabel yang ditentukan yaitu $1,87>1,64$, yang berarti hipotesis empat diterima, bahwa gaya kepemimpinan mampu memoderasi secara positif pengaruh antara anggaran partisipasi terhadap kinerja sekolah sehingga dapat dijelaskan bahwa semakin tinggi gaya kepemimpinan maka semakin memberikan penguatan pengaruh antara penganggaran partisipatif terhadap kinerja.

Hasil penelitian ini memberikan bukti bahwa penganggaran partisipatif berpengaruh terhadap kinerja sekolah dengan melihat nilai koefisien yang bertanda positif yang dapat diartikan dengan keterlibatan stakeholder (tenaga pendidik, tenaga kependidikan dan komite) dalam berpartisipasi untuk penyusunan anggaran pendapatan dan belanja sekolah maka akan meningkatkan kinerja sekolah. Hasil empiris dari penelitian ini memberikan penguatan dari penelitian sebelumnya yang menjelaskan bahwa terdapat pengaruh antara partisipasi anggaran terhadap kinerja, diantaranya Brownel dan McInes (1986), Sardjito dan Muhtaher (2007), dan Sutrisna (2011).

Berdasarkan hasil pengujian hipotesis didapatkan nilai total effect yang mempunyai nilai lebih besar dari kriteria koefisien nilai $\mathrm{T}$ yang ditentukan maka hipotesis kedua diterima artinya, komitmen organisasi dapat memoderasi pengaruh penganggaran partisipatif terhadap kinerja. Pada nilai koefisien yang didapatkan dari hasil analisis menunjukkan tanda positif 
berarti bahwa komitmen organsiasi dapat memberikan penguatan pengaruh penganggaran partisipatif terhadap kinerja sekolah. Hasil empiris dari penelitian ini memberikan penguatan dari penelitian sebelumnya yang menjelaskan bahwa komitmen organisasi dapat menjadi variabel moderasi pada pengaruh antara penganggaran partisipatif terhadap kinerja, diantaranya Sugiyanto (2005), Cahyadi (2010), dan Indarto (2011).

Hipotesis ketiga menyatakan bahwa budaya organisasi dapat memoderasi pengaruh penganggaran partisipatif terhadap kinerja. Berdasarkan hasil pengujian hipotesis didapatkan nilai total effect lebih kecil dari kirteria nilai $\mathrm{T}$ yang ditentukan sehingga budaya organsiasi tidak dapat dijadikan variabel moderasi pada pengaruh anggaran partsipaif terhadap kinerja. Secara empiris penelitian ini didukung oleh penelitian sebelumnya yaitu: Eritrina (2015) dan Agusti (2012) yang menunjukkan tidak terdapat pengaruh antara budaya organsiasi terhadap kineja manajemen dan budaya organsasi tidak dapat menjadi variabel moderasi pada pengaruh penganggaran partisipatif terhadap kinerja pegawai. Sementara, hasil temuan ini bertentangan dengan hasil temuan dari Nazaruddin (2012) dan Mariam (2009) yang menjelaskan bahwa variabel budaya organisasi dapat memperkuat pengaruh antara penganggaran partisipatif terhadap kinerja.

Hipotesis keempat menyatakan bahwa gaya kepemimpinan dapat memoderasi pengaruh penganggaran partisipatif terhadap kinerja. Berdasarkan hasil pengujian hipotesis didapatkan nilai total effect melebihi kriteria koefisien nilai T yang ditentukan. Pada nilai koefeisien menunjukkan tanda positif hal ini berarti bahwa gaya kepemimpinan dapat memberikan penguatan pengaruh penganggaran partisipatif terhadap kinerja sekolah. Dapat diartikan bahwa semakin tinggi nilai gaya kepemimpinan maka akan memperkuat pengaruh penganggaran partisipatif terhadap kinerja. Hasil empiris dari penelitian ini memberikan penguatan dari penelitian sebelumnya yang menjelaskan bahwa gaya kepemimpinan dapat menjadi variabel moderasi pada pengaruh antara penganggaran partisipatif terhadap kinerja, diantaranya Himawan (2010) dan Mariam (2009)

Hasil penelitian ini dapat mendukung teori behavior yang menejaskan bahwa kinerja suatu organsiasi dapat dipengaruhi oleh perilaku seseorang. Hasil empiris yang terdapat di sekolah terkait dengan penyusunan anggaran, maka semakin stakeholder dilibatkan dalam penyusunan anggaran maka akan memberikan kontribusi pada perilaku kerja yang nantinya akan memberikan dampak pada peningkatan kinerja. Sementara itu, hasil penelitian ini juga mendukung teori kontijensi yang lebih mengarah ketidakpastian suatu sisem yang diterapkan dalam organsiasi yang unviersal, diantara komitmen organisasi dan 
gaya kepemimpinan sebagai suatu bentuk faktor lingkungan yang mendukung pada ketercapaian tujuan organisasi maka akan meningkatkan kinerja sekolah. Sementara dalam penelitian ini, budaya organsiasi tidak mampu menjadi variabel moderasi, tetapi lebih cenderung sebagai variabel independen untuk meningkatkan kinerja organisasi dengan mengacu pada teori organsiasi.

\section{SIMPULAN}

Penganggaran partisipatif berpengaruh terhadap kinerja sekolah, dengan pengujian regresi secara langsung menunjukkan bahwa penganggaran partisipatif mempunyai pengaruh positif terhadap kinerja sekolah. hal ini memberikan penguatan pada penelitian terdahulu bahwa angggaran partisipatif mampu mempengaruhi kinerja manajerial. Variabel moderasi yang dipakai dalam penelitian yaitu komtimen organisasi, budaya organisasi, dan gaya kepemimpinan mempunyai hasil yang berbeda-beda. Komitmen dan gaya kepemimpinan mampu memoderasi dalam pengaruh anatara penganggaran partisipatif terhadap kinerja. Variabel budaya organisasi tidak dapat memoderasi pengaruh budaya organisasi terhadap kinerja.

Komitmen organisasi yang tinggi dan dimiliki oleh anggota organisasi mampu memberikan penguatan terhadap kinerja dengan melihat pengaruh dari kesempatan anggota dalam berpartisipasi terhadap anggaran. Gaya kepemimpinan yang mampu mengarahkan bawahan dalam melakukan kerja mampu memberikan penguatan saat anggota organisasi dilibatkan dalam berpartisipasi membentuk anggaran dan dapat meningkatkan kinerja anggota organisasi.

Saran untuk penelitian berikutnya adalah memperluas populasi penelitian tidak hanya terbatas pada SMK tetapi pada institusi pendidikan lainnya, harapan untuk penelitian selanjutnya yaitu dengan penambahan variabel lainnya seperti motivasi kerja dan sebagainya sebagai variabel moderasi ataupun mediasi dalam mengukur kinerja.

\section{DAFTAR RUJUKAN}

,Badan Akreditasi Nasional Sekolah Menengah. (2015). www. BAN-SM.or.id.

Tanggal akses 15 Maret 2016.

Abdullah dan Arisanti. (2010). Pengaruh Budaya Organisasi, Komitmen Organisasi Dan Akuntabilitas Publik Terhadap Kinerja Organisasi.Jurnal Ekonomi Dan Bisnis 9(2): 118-134.

Abuddinata. (2003). Manajemen Pendidikan. Kencana. Jakarta 
Amold, H.J. dan D.C. Feldman. (1986). Organizational Behavior, New York: McGraw-Hill Book Company.

Ardiansyah, Misnen.(2009). Penelitian Pengaruh Akuntansi Keperilakuan. Jurnal Sosioreligia. Vol.8(3):56-62.

Argyris .(1952). The Impact of People On Budgets. Controllership Foundation. New York.

Bahar. (2008). Keterbukaan Anggaran Melalui RAPBS / APBS Partisipasif. http://fadiloesbahar.blogspot.com/2008/08/keterbukaan-anggaran-melalui-rapbsapbs.html. Desember 2015.

Baswedan, A. (20140. Pendidikan Indonesia Gawat Darurat.http://www.Kompas.education.com. Februari 2016

Becker, S.W., (1967). Discussion of the Effect of Frequency of Feedback on Attitudes and Performance, Journal of Accounting Research, Vol 5 Supplement.

Biduri,S. (2013). Pengaruh Partisipasi Penyusunan Anggaran Terhadap Kinerja Manajerial Dengan Variabel Pemoderasi Gaya Kepemimpinan dan Komitmen Organisasi Pada Pemerintah Daerah Kabupaten Lamongan. Jurnal Media Mahardhika 11(2):69-88.

Brownell, P. (1982). A Field Study Examination Of Budgetary Participation And Locus Of Control. Journal The Accounting Review. 4 (57): 766.

Brownell, p. dan M. Hirst. (1986). Reliance on Accounting Information,Budgetary Participation and Task Uncertainty: Tests of a Threeway Interaction. Journal of Accounting Research 24 (2): 241-251.

Cahyadi,R.S. (2010). Pengaruh Komitmen Organisasi, Gaya Kepemimpinan dan Ketidakpastian Lingkungan Terhadap Hubungan Penganggaran partisipatif Dengan Kinerja Manajerial. Jurnal Akuntansi Kontemporer 2(2):171-189.

Direktoral Pembinaan Sekolah Menengah Kejuruan. (2015). www.ditpsmk.net.

Direktorat Tenaga Kependidikan. (2007). Kepemimpinan Kepala Sekolah dalam Meningkatkan Sumber Daya Manusia di Sekolah Dasar. http://www.14-b1kepemimpinan-kepala sekolah-dalam-meningkatkan-SDM. Januari 2016

Elya, Kurniawati, 2013. Pengaruh Gaya Kepemimpinan dan Budaya Organisasi terhadap Kinerja Karyawan serta Dampaknya pada Kepuasan Kerja Karyawan, Studi pada PT. Jasa Marga (Persero) Kantor Cabang Surabaya. Jurnal Aplikasi Manajemen Vol 11(4). Universitas Brawijaya. Malang

Eritrina, Hana.N. (2015). Pengaruh Penganggaran partisipatif Terhadap Kinerja Manajerial : Komitmen Orgnasasi, Budaya Organsasi dan Desentraliasasi sebagai Variabel Moderating (Studi pada Instansi Vertikal Kementrian Pertanian di Provinsi Jawa Timur). Tesis. Universitas Brawijaya.

Faisal, A.(2009). Pemecahan Masalah Manajemen Keuangan Sekolah. http://ahmadfaisal2.blogspot.com. Desember 2015

Garrison, Noreen, and Brewer, (2007). Managerial Accounting, AkuntansiManajerial, edisi 11, diterjemahankan oleh Nuri Hinduan dan Edwart tanujaya.Penerbit Graha Ilmu. Yogyakarta.

Gerdin,J. dan Greve, J. (2004). Forms Of Contigency Fit In Management Accounting Research. Journal Accounting, Organizatinal and Society 29 : 303 - 326.

Gibson, dkk.(1995).Organisasi: Perilaku, Struktur, Proses, Jilid 2, Binarupa Aksara. Jakarta. Hanafi, Ivan. (2015). Analisis Implementasi Kebijakan Pendidikan: Peran Komite Sekolah Pada Sekolah Menengah Kejuruan. Journal Cakrawala Pendidikan. Februari 2015 No. 1

Hartono , J. dan Abdillah, W. (2015). Partial Least Square (PLS). Alternatif SEM dalam Penelitian Bisnis. BPFE. Yogyakarta 
Hartono, J. (2014). Metodologi Penelitian Bisnis, Salah Kaprah dan PengalamanPengalaman. : BPFE.Yogyakarta

Hersey, Paul and Blanchard, (1982). Management of Organizationalbehavior, utilizing human resources.4th edition. Prentice-hall, Inc. AgusDharma (penerjemah).

ManajemenPerilaku Organisasi.Pendayagunaan Sumber DayaManusia. Edisi ke 4.. Erlangga. Jakarta

Himawan, A.K.(2010). Pengaruh Komitmen Organsiasi, Gaya Kepemimpinana dan JRI terhadap hubungan anatara penganggaran partisipatif dan Kinerja Manajerial (studi Empiris pada BPR di Kota Semarang). AKSES : Jurnal Ekonomi dan Bisnis 5(9): 6579.

Ikhsan, S. (2010). Penerapan MBS SMK Negeri dan Swasta. Jurnal Pendidikan Ekonomi dan Dinamika Pendidikan 5(1): 1-19.

Indarto, S.L. (2011). Pengaruh Partisipasi dalam Penyusuanan Anggaran Terhadap Kinerja Manajerial Perusahaan Melalui Kecukupan Anggaran, Komitmen Organsiasi, Komitmen Tujuan Anggaran, dan Job Relevant Information (JRI). Jurnal Seri Kajian Ilmiah 14(1): 1-44.

Jakarta Kurniawan,M. (2011). Pengaruh Komitmen Organisasi, Budaya Organisasi,dan Kepuasan Kerja Terhadap Kinerja Organisasi Publik. Jurnal Akuntansi Vol 2. Universitas Diponegoro.

Kartono.(2006). Pemimpin dan Kepemimpinan, Apakah Kepemimpinan Abnormal Itu?. Raja Grafindo Persada. Jakarta

Lumpkin, G., \& Dess, G. (2001). Linking Two Dimensions of Entrepreurial Orientation to Firm Performance. The Moderating Role of Environment and Industry Life Cycle. Journal of Business Venturing, 10 (2)

Mardiasmo. (2009). Akuntansi Sektor Publik. Andi. Jakarta

Mariam, R. (2009). Pengaruh Gaya Kepemimpinan dan Budaya Organisasi Terhadap Kinerja Karyawan Melalui Kepuasan Kerja Karyawan Sebagai Variabel Intervening. Tesis. Universitas Diponegoro.

Mayer J.P. Allen NJ.(1997). Three-Component Conceptualization and Performance: An Organizational Prespective. Journal of Service Marketig. Vol.20. Hal:136-147

Monday, R.T.,R.M. Streers dan L.W. Porter. 1979. The Measurement of Organizational Commitmen. Journal of Vacational Behavior. Vol.14, pp. 224-247

Muhroji. (2012). Pengaruh Sarana dan Biaya Pendidikan Terhadap Hasil Belajar di Sekolah Menengah. Jurnal Pendidikan Ilmu Sosial, Vol. 22, No. 2, 93 - 102.

Mulyadi. (2001). Strategic Management System Dengan Pendekatan Balanced Scorecard. Jurnal Usahawan 02 : 39-46.

Nafarin, M. (2004).Penganggaran Perusahaan. Salemba Empat. Jakarta.

Nawawi. (2004). Evaluasi Kinerja dan Pengawasan. Gadjah Mada Offset. Yogyakarta Nazaruddin, Ietje.(2012). Pengaruh Partisipasi Penyusunan Anggaran Terhadap Kinerja Aparat Pemerintah Daerah Dengan Budaya Organisasi, Komitmen Organisasi, Motivasi, Desentralisasi, Dan Job Relevant Information Sebagai Variabel Moderasi. Jurnal Akuntansi dan Investasi Vol. 12 (2) hal : 197-207

Nor, W. (2007). Desentralisasi dan Gaya Kepemimpinan Sebagai Variabel Moderating dalam Hubungan Anatara Partisipasi Penyusunan Anggaran dan Kinerja Manajerial.Simposium Nasional Akuntansi X.Pp 1-27.

Nurjanah. (2008). Pengaruh Gaya Kepemimpinan dan Budaya Organisasi TerhadapKomitmen Organisasi Dalam Meningkatkan Kinerja Karyawan. Tesis. Universitas Diponegoro. 
Otley,D.T. (1978). Budget Use And Managerial Performance.Journal of Accounting Research : 122-149

Peraturan Pemerintah Republik Indonesia No. 19 tahun 2005. StandarPendidikan Nasional.

Peraturan Pemerintah Republik Indonesia No. 32 tahun 2013. Perubahan Atas PP no 19 tahun 2005 Tentang StandarPendidikan Nasional.

Rasto. (2010). Mutu kinerja Sekolah Menengah Kejuruan Yang Berdaya Saing. Studi Tentang Pengaruh Kepemimpinan Kepala Sekolah, Manajemen Informasi, Fokus Pada Pelanggan, Perencanaan Strategik, Pengembangan Sumberdaya Manusia, Kemitraan Sekolah dan Budaya Mutu Terhadap Kinerja Sekolah Menengah Kejuruan di Cimahi. Disertasi. Pascasarjana Universitas Pendidikan Indonesia.

Rivai, Veithzal dan Basri. (2005). Performance Appraisal: Sistem Yang Tepat Untuk Menilai Kinerja Karyawan Dan Meningkatkan Daya Saing Perusahaan.PT Raja Grafindo Persada. Jakarta.

Robbins, dan Stephen.P. (2003). Perilaku Organisasi.Edisi Bahasa Indonesia. Indeks Kelompok Gramedia. Jakarta.

Ronald O'reilly. (2003). Manajemen Sumber Daya Manusia. Prestasi Pustaka. Jakarta

Sardjiito dan Muthaher. (2007). Pengaruh Partisipasi Penyusunan Anggaran Terhadap Kinerja Aparat Pemerintah Daerah: Budaya Organisasi dan Komitmen Organisasi Sebagai Variabel Moderating. Simposium NasionalAkuntansi X. Makasar.

Sholihin, Mahfud dan Ratmono, Dwi. (2013). Analisis SEM-PLS dengan WrapPLS 3.0 Untuk Hubungan Nonlinear dalam Penelitian Sosial dan Bisnis. Penerbit ANDI. Yogyakarta

Singarimbun dan Effendi.(2006). Metode Penelitian Survei. LP3ES. Jakarta

Sugiyanto, E.(2005). Pengaruh Penganggaran partisipatif Terhadap Kinemrj Manajerial: Komitmen Tujuan Sebagai Variabel Intervening (Studi Empiris PAda Rumah Sakit Tipe A,B dan C di Jawa Tengah dan DIY). Jurnal BENEFIT 9(1): 34-48.

Suharto dan Cahyo. (2005). Pengaruh Budaya Organisasi, Kepemimpinan dan Motivasi Terhadap Kinerja Sumber Daya Manusia di Sekretariat DPRD Propinsi Jawa Tengah. Jurnal Riset dan Bisnis Indonesia 1(1): 13-30.

Sumarno. (2005). Pengaruh Komitmen Oganisasi dan Gaya Kepemimpinan Terhadap Hubungan Natara Penganggaran partisipatif dan Kinerja Manajerial. Simponsium Nasional Akuntansi, Solo.

Sutrisna,A.(2011). Pengaruh Partisipasi Dalam Penyususnan Anggaran Terhadap Kinerja Manajerial Pemerintah Kota Yogyakarta Dengan Pendekatan Kontigensi.Jurnal ASSETS 1(2): 161-175.

Tangkilisan. (2007). Manajemen Publik. PT.Grasindo. Jakarta 